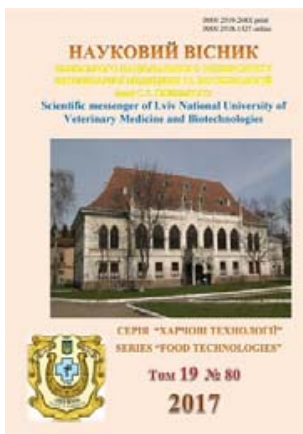

Науковий вісник Львівського національного університету ветеринарної медицини та біотехнологій імені С.3. Гжицького

Scientific Messenger of Lviv National University of Veterinary Medicine and Biotechnologies

doi:10.15421/nvlvet8005

ISSN 2519-268X print

ISSN 2518-1327 online

http://nvlvet.com.ua/

УДК 637.33

\title{
Удосконалення технології дрібного твердого сиру 3 метою виробництва на малих сироробних підприсмствах
}

\author{
Л.М. Кітченко \\ lyudmila_kitchenko@ukr.net \\ Сумський національний аграрний університет, \\ вул. Г. Кондратьєва, 160, м Суми, 40021, Україна
}

\begin{abstract}
У статті розглянуто новий етап розвитку молочної промисловості Украӥни - формування на ринку сегменту сучасних сироробних підприємств, які переробляють молоко в малих об'ємах, розміщені поблизу від джерел сировини $і$ споживачів. Такий принцип переробки сировини має переваги, але виробництво сиру на малих підприємствах зробило ухил на розвиток асортименту м'яких сирів. Тому є необхідість запропонувати виробникам малих сироварень технологію дрібного твердого сиру з метою розширення асортименту та зробити його доступним за ціновою політикою для вживання певному колу споживачів. Особливістю розробленої технології є використання молока власного навчально-дослідного господарства «Віварій», проведені досліди на визначення сиропридатності молока для виробництва твердого сиру; використання визначених пропіоновокислих культур, формування сиру у малих формах, щзо дає можливість отримати головки невеликої ваги. Наведені температурні режими процесу дозрівання дрібного твердого сиру без покриття та у покритті з латексного матеріалу та з натуральним воском. Проведені дослідження стосовно визначення кількості пропіоновокислих мікроорганізмів на різних термінах дозрівання та динаміки білкового розпаду в процесі дозрівання у головках сиру із різними видами покриття, встановлено термін дозрівання дрібного твердого сиру. Визначено хімічний склад та зроблена органолептична оцінка якості зрілого сиру, згідно з якою відзначено, що смакові властивості дрібного твердого сиру подібні до великого твердого сиру. Удосконалена технологія виробництва сиру дрібного твердого може бути запропонована малим сироробним підприсмствам для розширення асортименту.

Ключові слова: малі сироробні підприємства дрібний твердий сир, технологія, пропіоновокислі культури, дозрівання, латексне покриття, покриття із натуральним воском, азотовмісні фракиії, білковий розпад, хімічний скла, органолептичні показники
\end{abstract}

\section{Усовершенствование технологии мелкого твердого сыра с целью выработки на малых сыродельных предприятиях}

\author{
Л.Н. Китченко \\ lyudmila_kitchenko@ukr.net \\ Сумский наииональный аграрний университет, \\ ул. Г. Кондратьева, 160, г.Сумы, 40021, Украина
}

\begin{abstract}
В статье рассмотрен новый этап развития молочной промылиленности Украины - формирование на рынке сегмента современных сыродельных предприятий, которые перерабатывают молоко в малых объемах, находятся в непосредственной близости к источникам сырья и потребителям. Такой принцип переработки сырья имеет преимущества. Но производство сыра на малых предприятиях сделало уклон на развитие ассортимента мягких сыров. Поэтому есть необходимость предложить производителям малых сыроварен технологию мелкого твердого сыра с иелью расширения ассортимента и сделать его доступным по иеновой политике для употребления определенному кругу потребителей. Особенностью разработанной технологии является использование молока собственного учебно-опытного хозяйства «Виварий», проведены опыты по определению сыропригодности молока для производства твердого сыра; использованию определенных пропио-
\end{abstract}

Citation:

Kitchenko, L.M. (2017). Improvement of small hard cheese technology aimed at production in minor cheese-making enterprises. Scientific Messenger LNUVMB, 19(80), 25-28. 
новокисльх культур, формированию сыра в мальх формах, что дает возможность получить головки небольшого веса. Приведены температурные режимы процесса созревания мелкого твердого сыра без покрытия и в покрытиях из латексного материала и покрытия с натуральным воском. Проведены исследования по определению количества пропионовокислых микроорганизмов на разных сроках созревания и динамики белкового распада в процессе созревания в головках сыра с разными видами покрытия, установлен срок созревания мелкого твердого сыра. Определен химический состав и произведена органолептическая оценка качества зрелого сыра, согласно которой отмечено, что вкусовые свойства мелкого твердого сыра подобны большому твердому сыру. Усовершенствованная технология производства сыра мелкого твердого может быть предложена мальм сыродельным предприятиям для расширения ассортимента.

Ключевые слова: малье сыродельные предприятия, мелкий твердый сыр, технология, пропионовокислье культуры, созревание, латексное покрытие, покрытие с натуральным воском, азотсодержашчие фракции, белковый распад, химический состав, органолептические показатели.

\title{
Improvement of small hard cheese technology aimed at production in minor cheese-making enterprises
}

\author{
L.M. Kitchenko \\ lyudmila_kitchenko@ukr.net \\ Sumy National Agrarian University, \\ G. Kondratiev Str., 160, Sumy, 40021, Ukraine
}

\begin{abstract}
The article considers a new stage in the development of the dairy industry in Ukraine - the formation of a modern segment of cheese-processing enterprises in the market segment that processes milk in small volumes, located directly close to the sources of raw materials and consumers. Such a principle of processing of raw materials has advantages, but the production of cheese at small enterprises has made a slope for the development of a range of soft cheeses. Therefore, there is a need to offer small cheesecake producers the technology of fine hard cheese to expand the range and make it affordable for pricing policies for the use of a certain range of consumers. The peculiarity of the developed technology is the use of milk from Vivarium's own educational and research farm, experiments on the determination of milk cheese dairy cheese for the production of hard cheese; the use of certain propionic cultures, the formation of cheese in small forms, which makes it possible to obtain heads of small weight. The temperature regimes of the maturation process of small hard cheese without coating and in the coating of latex material and natural wax are given. Studies have been carried out on the determination of the amount of propionicacid microorganisms at different terms of ripening and the dynamics of protein degradation in the process of ripening in cheese heads with different types of coating, and the maturing date of fine hard cheese has been established. The chemical composition has been determined and the organoleptic assessment of the quality of mature cheese has been made, according to which it is noted that the taste properties of the small hard cheese are similar to the large hard cheese. The improved technology of production of fine hard cheese can be offered to small cheese-making enterprises to expand the range.
\end{abstract}

Key words: small dairy enterprises, small cheese, technology, propionic acid culture, maturation, latex coating, natural wax coating, nitrogen-containing fractions, protein degradation, chemical composition, organoleptic parameters.

\section{Вступ}

Сьогодні, незважаючи на кризові явища, в молочній промисловості України настав новий етап розвитку цієї галузі - формування на ринку сегменту сучасних сироварних підприємств, які переробляють молоко в малих об'ємах, розміщені поблизу від джерел сировини і споживачів (Gudkov, 2003; Snezhko et al., 2006; Vlasova and Cugkiev, 2010; Kriger and Belov, 2010). Цей принцип переробки дозволяє отримати такі переваги:

- якнайповнішу переробку молока, наявного у населення;

- скорочення витрат на доставку сировини та іiі переробку, а також реалізацію готової молочної продукції, тим самим істотно знижуючи вартість молочних продуктів; кції;

- оперативно варіювати спектр виробленої проду-

- досягти високого ступеня реалізації продукції.

Але виробництво сиру на малих підприємствах зробило ухил на розвиток асортименту м'яких сирів, який дозволяє виробнику прискорити обіг грошових коштів і в умовах зниження якості молока-сировини забезпечити випуск якісної продукції. Асортимент сирів малих підприємств представлений м'якими, розсільними сирами та іноді сирами з чеддеризацією і термомеханічною обробкою сирної маси.

Розширення виробничих площ для облаштування камер дозрівання та зберігання продукції уможливлює збільшення асортименту сирів шляхом виробництва не тільки напівтвердих сирів типу російського та голландського, а й відомих сирів далекого зарубіжжя - напівтвердого типу Маасдам та твердого - типу Пармезан, завдяки чому певне коло споживачів, завдяки ціновій політиці, буде мати можливість дозволити собі придбати такий сир.

\section{Матеріал і методи досліджень}

Враховуючи ці тенденції, на кафедрі технології молока і м'яса СНАУ було розроблено технологію дрібного твердого сиру з органолептичними показниками аналогічними твердому сиру типу пармезан смак пряний, солодкуватий, консистенція тверда, крихка, малюнок відсутній. При розробці технології насамперед враховувалися такі фактори, як якість та хімічний склад молока-сировини, його сиропридатність; заквасочні культури, які забезпечують важливі біохімічні та мікробіологічні процеси в технології 
виробництва твердого сиру та сприяють формуванню в ньому встановлених органолептичних показників.

Для досліджень вибрані такі об'єкти:

- молоко-сировина;

- сир твердий;

- заквасочні культури: ліофілізована термофільна культура, яка містить штам Propionibacterium freudenreichii subsp. Shermanii (PS-4) із додаванням інших культур цієї серії PS-1 та PS-2. В експериментах використовували стандартні методи досліджень. Повторюваність дослідного виробітку сиру та дослідження зразків сиру - триразова.

\section{Результати та їх обговорення}

Експериментальні виробки сирів проводили у навчальній лабораторії кафедри технології молока i м'яса СНАУ із молока, отриманого від корів власного навчально-дослідного господарства «Віварій».

При визначенні сиропридатності молока визначались такі показники: м. ч. жиру $-3,4 \%$; м. ч. білка $3,1 \%$; густина - 1,030 г/ $\mathrm{cm}^{3}$; сичужно-бродильна проба - 1 клас; соматичні клітини - 400 тис. КОЕУ/мл; інгібуючі речовини - відсутні, маслянокислі мікроорганізми - відсутні. Виробництво сиру відбувалося із молока вечірнього знежиреного та ранішнього незбираного, не раніше, ніж через 2 години після доїння.

Підготовка молока: термічна обробка - термізація $-65^{\circ} \mathrm{C}$, дозрівання - 10 годин; пастеризація $-72{ }^{\circ} \mathrm{C}$.

Ключові моменти: температура згортання суміші: 32-33 ${ }^{\circ} \mathrm{C}$, селітра та барвники - відсутні; розрізання згустку та постановка зерна - 30-35 хв, видалення сироватки $40 \%$, додавання пастеризованої води $-20 \%$ від об'єму суміші, температура 2 нагрівання - 52-
$54{ }^{\circ} \mathrm{C}$; формування: - підпресування під пластом сироватки, розрізання на бруски 1 кг (згідно з об'ємом форм) пресування у формах при поступовому збільшенні тиску від 2 до 7 МПа протягом 4-6 годин; $\mathrm{pH}$ сиру після преса $-5,5-5,6$, м. ч вологи $-41-42 \%$; м. ч. жиру після преса $-45-46 \%$.

Соління сиру - 12-14 годин; дозрівання сиру проходило у 3 етапи: 1 етап - 10 діб при 10-11 ${ }^{\circ} \mathrm{C} ; 2$ етап - 21 доба при 19-20 ${ }^{\circ} \mathrm{C}$; 3 етап - 10 діб при 12-14 ${ }^{\circ} \mathrm{C}$ та відносній вологості 90-92\%

Проведено 3 серії варок із - термофільною культурою, яка містить визначений штам Propionibacterium freudenreichii subsp. shermanii (PS-4) із додаванням інших культур цій серії PS -1 і PS - 2. Сири I серії (контроль) дозрівали без покриття. Після дозрівання сиру в теплій камері на дослідні зразки наносилося покриття: для сирів 2 серії - латексне, на сири 3 серії - покриття із натуральним воском. На різних етапах дозрівання проводилося визначення кількості пропіоновокислих бактерій, результати подані у таблиці 1 .

Таким чином, характер розмноження пропіоновокислих бактерій у трьох зразках був однаковим до процесу дозрівання. Життєздатність клітин пропіоновокислих бактерій вища у дослідних зразках.

При догляді за сирами візуально було встановлено кінець дозрівання на 30-35 добу, що експериментально доведено показниками, поданими у таблиці 2.

Показники накопичення продуктів розщеплення білків є об'єктивними при оцінці процесу дозрівання сиру. Результати експериментального вивчення продуктів білкового розпаду свідчать про закінчення даного процесу в 35-добовому віці сирів. Аналіз даних таблиці 2 показав, що процес протеолізу активніше протікав у дослідних зразках сиру.

Таблиия 1

\section{Визначення кількості пропіоновокислих бактерій}

\begin{tabular}{|l|c|c|c|c|c|}
\hline \multirow{2}{*}{ Варіанти дослідного сиру } & \multicolumn{4}{|c|}{ Кількість пропіоновокислих бактерій, тис./г } \\
\cline { 2 - 6 } & Після пресування & Після соління & 15 діб & 30 діб & 45 діб \\
\hline Зразок 1 (без покриття контроль) & 6,1 & 4.0 & 900 & 520 & 190 \\
\hline Зразок 2 (дослідний із латексним покриттям) & 6,3 & 4,1 & 1100 & 620 & 400 \\
\hline $\begin{array}{l}\text { Зразок 3 (дослідний - покриття з натуральним } \\
\text { воском) }\end{array}$ & 6,4 & 4,1 & 1200 & 650 & 460 \\
\hline
\end{tabular}

Динаміка загальних азотовмісних фракцій у дрібному твердому сирі

\begin{tabular}{|l|c|c|c|}
\hline \multicolumn{1}{|c|}{ Варіанти опитного сиру } & $\begin{array}{l}\text { Загальний розчин- } \\
\text { ний азот, } \%\end{array}$ & $\begin{array}{l}\text { Небілковий розчин- } \\
\text { ний азот, } \%\end{array}$ & Амінний азот, $\%$ \\
\hline Зразок 1 (без покриття контроль) & 25,4 & 12,5 & 8,5 \\
\hline Зразок 2 (опитний із латексним покриттям) & 26,95 & 16,05 & 9,5 \\
\hline Зразок 3 (опитний покриття 3 натуральним воском) & 25,2 & 16,0 & 9,3 \\
\hline
\end{tabular}

Хімічний склад та органолептичні показники дрібного твердого сиру

\begin{tabular}{|c|c|c|c|c|c|}
\hline \multirow[b]{2}{*}{$\begin{array}{c}\text { Варіанти дослідного } \\
\text { сиру }\end{array}$} & \multicolumn{3}{|c|}{ Хімічний склад \% } & \multicolumn{2}{|c|}{ Органолептичні показники } \\
\hline & М. ч. ж & М. ч. в & М. ч. солі & Смак та запах & $\begin{array}{c}\text { Малюнок, } \\
\text { консистенція }\end{array}$ \\
\hline Зразок 1 (без покриття) & 45,0 & 39,0 & 1,5 & $\begin{array}{l}\text { Пікантний, насичений, тонкий аро- } \\
\text { мат, притаманний твердому сиру, без } \\
\text { сторонніх присмаків та запахів }\end{array}$ & $\begin{array}{l}\text { Без малюнка; } \\
\text { однорідна, щільна, } \\
\text { тісто крихке }\end{array}$ \\
\hline $\begin{array}{l}\text { Зразок } 2 \text { (дослідний із } \\
\text { латексним покриттям) }\end{array}$ & 45,2 & 38,5 & 1,5 & $\begin{array}{l}\text { Пікантний, насичений, тонкий аро- } \\
\text { мат, притаманний твердому сиру, без } \\
\text { сторонніх присмаків та запахів }\end{array}$ & $\begin{array}{l}\text { Без малюнка; } \\
\text { однорідна, щільна, } \\
\text { тісто крихке }\end{array}$ \\
\hline $\begin{array}{l}\text { Зразок } 3 \text { (дослідний } \\
\text { покриття } 3 \text { натуральним } \\
\text { воском) }\end{array}$ & 45,0 & 38,0 & 1,5 & $\begin{array}{l}\text { Пікантний, насичений, тонкий аро- } \\
\text { мат, притаманний твердому сиру, без } \\
\text { сторонніх присмаків та запахів }\end{array}$ & $\begin{array}{l}\text { Без малюнка; } \\
\text { однорідна, щільна, } \\
\text { тісто крихке }\end{array}$ \\
\hline
\end{tabular}


Хімічний склад та органолептична оцінка свідчить про відповідність показників сиру дрібного твердого показникам сиру твердого.

\section{Висновки}

1. При виробництві дрібного твердого сиру необхідно сирний пласт розрізати на бруски, які утворюють головку сиру не більше ніж 1 кг.

2. Активність розвитку пропіоновокислої мікрофлори у дослідних зразках дрібних твердих сирів була вищою, ніж у контрольному, що сприяло накопиченню ароматоутворюючих речовин і утворенню відповідного пряного горіхового смаку.

3. При проведенні процесу дозрівання після 2 етапу необхідно на головки сиру наносити захисне покриття латексного матеріалу або матеріалу з додаванням натурального воску.

Перспективи подальших досліджень:

1. Удосконалення процесу дозрівання дрібних твердих сирів у різних видах полімерного покриття.

2. Розробка технології дрібних напівтвердих сирів 3 високою температурою другого нагрівання для виробництва на малих сироробних підприємствах.
3. Розробка технології напівтвердого сиру з високим рівнем молочнокислого бродіння для виробництва на малих сироробних підприємствах.

\section{Бібліографічні посилання}

Vlasova, Zh.A., Cugkiev, B.G. (2010). Kachestvo moloka dlja proizvodstva syra. Syrodelie i maslodelie. 4, 3435 (in Russian).

Gudkov, A.V. (2003). Syrodelie: tehnologicheskie, biologicheskie i fiziko- himicheskie aspekty. M.: DeLi print (in Russian).

Kriger, A.V., Belov, A.N. (2010). Vlijanie fermentnyh kompozicij na proteoliz $\mathrm{v}$ syrah. Syrodelie i maslodelie. 3, 38-40 (in Russian).

Snezhko, A.G., Novikov, V.M., Borisova, Z.S. (2006). Sovremennye bar'ernye tehnologii zashhity poverhnosti tverdyh syrov. Syrodelie i maslodelie. 5, 32-34 (in Russian).

Received 3.09.2017

Received in revised form 29.09.2017 Accepted 3.10.2017 